\title{
„Trzeba, abyś w Rzymie zaświadczył o Mnie” (Dz 23, 11b). Rzym w Dziejach Apostolskich
}

Księga Dziejów Apostolskich jest „monografią historyczną” pierwotnego Kościoła, która obejmuje około trzydzieści lat życia i działalności pierwszych wspólnot uczniów Chrystusa. Jak stwierdza jeden ze współczesnych autorów żydowskich, Dzieje Apostolskie „oferują prawdziwy wgląd w życie, sposób myślenia i aspiracje pierwszego pokolenia chrześcijan"1. Zgodnie z programem literackim i teologicznym wyrażonym na samym początku księga opowiada o rozszerzaniu się wiary w Jezusa, Mesjasza i Syna Bożego „w Jerozolimie, Judei, Samarii i aż po krańce ziemi" (Dz 1, 8). Głoszenie ewangelii Jezusa stanowiło centrum misyjnego zaangażowania Jego świadków, którzy opowiadali i przypominali życie i nauczanie Jezusa z Nazaretu oraz w świetle doświadczenia paschalnego coraz pełniej odkrywali działanie Boga w Nim i w życiu Jego uczniów. Ta radosna i pełna nadziei dobra nowina musiała dotrzeć do wielu, stąd autor z taką pasją opowiada o misyjnej działalności pierwotnego Kościoła, który niesie ewangelię coraz dalej „aż po krańce ziemi”. Nie dziwi zatem fakt, że w Dziejach Apostolskich, najczęściej w Nowym Testamencie, pojawia się nazwa Rzymu ('P $\left.{ }^{\prime} \mu \eta\right)$, stolicy cesarstwa rzymskiego: pięć razy $(18,2 ; 19,21 ; 23,11 ; 28,14.16)$, oprócz Dziejów Apostolskich jeszcze tylko w Rz 1, 7.15 oraz 2 Tm 1, $17^{2}$.

${ }^{1}$ G. Vermes, Twarze Jezusa, Kraków 2008, s. 185.

${ }^{2}$ Do tych miejsc można jeszcze dodać 1 P 5, 13, gdzie nie występuje wprost nazwa Rzym, ale autor listu wspomina „Babilon”, co jest powszechnie interpretowane jako odniesienie do stolicy cesarstwa: „Pozdrawia was wspólnota w Babilonie, wybrana razem z wami, a także Marek, mój syn”. Niektóre rękopisy (np. 2138) mają w miejscu „Babilon” nazwę „Rzym”. Nazwę dawnej stolicy imperium babilońskiego należy ro- 
Przedmiotem naszej refleksji będzie pięćtekstów zDziejów Apostolskich, w których pojawia się nazwa Rzym. Stawiamy pytanie o znaczenie tego miasta w drugiej części podwójnego dzieła Łukaszowego3: czy chodzi tylko o informacje natury geograficznej, związane z rozwojem i przemieszczaniem się chrześcijaństwa w kierunku stolicy imperium, czy należy raczej widzieć $\mathrm{w}$ tym pewien zamierzony przez autora program i znaczenie teologiczne.

\section{„Klaudiusz nakazał opuścić Rzym wszystkim Żydom” $(18,2)$}

Pod koniec drugiej wyprawy misyjnej, o której opowiadają Dzieje Apostolskie w 15, 36-18, 224, po pobycie w Atenach i znanej mowie na Areopagu $(17,16-34)$ Paweł przybył do Koryntu $(18,1)$ na początku 50 roku (luty-marzec) ${ }^{5}$. W tym czasie miasto ${ }^{6}$ liczyło ponad pół miliona mieszkańców. W czasach rzymskich zawdzięczało ono swój rozwój dogodnemu położeniu pod względem handlowym między dwoma morzami, a także wpływom administracji rzymskiej. Jednak mimo rozwoju gospodarczego Korynt nie stał się nigdy znanym ośrodkiem myśli

zumieć w sensie przenośnym jako kryptonim Rzymu. Podobnie w Ap 14, 8; 16, 19; 18, 2. 10. 21 oraz Apokalipsie Barucha $(11,1 ; 67,7 ; 77,12.17)$ - zob. S. Hałas, Pierwszy List św. Piotra, Częstochowa 2007, s. 350. 355-356. Podobnie J. Gnilka, Piotr i Rzym. Obraz Piotra w pierwszych dwu wiekach, Kraków 2002, s. 131, uważa, że „Pierwszy List Piotra wpisuje się w żydowsko-chrześcijańską tradycję apokaliptyczną, w której symboliczne imię „Babilon” zaczęto nadawać Rzymowi, jako miejscu bezbożności i występku”.

${ }^{3}$ Powszechnie przyjmuje się dzisiaj opinię, że Łukasz jest autorem zarówno Ewangelii, jak i Dziejów Apostolskich. Często mówi się o dwudziele Łukaszowym - zob. J. Załęski, Teofil w kontekście prologu w dziele Łukasza (Łk 1, 1-4; Dz 1, 1-2), [w:] W. Chrostowski, Ex Oriente Lux. Księga pamiątkowa dla Księdza Profesora Antoniego Troniny w 65. rocznicęurodzin, Warszawa 2010, s. 609, przypis 2 wraz z wieloma odniesieniami bibliograficznymi.

${ }^{4}$ Szczegółowiej na temat drugiej wyprawy misyjnej zob. W. Rakocy, Paweł Apostoł ̇̇ydów i pogan. Łukaszowy obraz powstania i rozwoju Pawłowych wspólnot, Kraków 1997, s. 83-117.

${ }^{5}$ Datację życia i pism Apostoła przyjmujemy za W. Rakocy, Paweł Apostoł. Chronologia życia i pism, Częstochowa 2003. Tablica chronologiczna życia i piśmiennictwa apostoła Pawła znajduje się na s. 385-387.

${ }^{6} \mathrm{Na}$ temat Koryntu zob. M. Rosik, Pierwszy List do Koryntian, Częstochowa 2009, s. 29-42, gdzie autor omawia kolejno położenie geograficzne miasta, rys historyczny, infrastrukturę miasta w czasach rzymskich, ekonomię, przemysł, sztukę, a także początki chrześcijaństwa w Koryncie. 
filozoficznej czy literackiej tak jak Ateny. Słynął jednak jako miejsce i jednocześnie symbol niemoralności i rozwiązłego życia?.

Według Dziejów Apostolskich, kiedy Paweł przybył do Koryntu z oddalonych około $60 \mathrm{~km}$ Aten, znalazł oparcie w żydowskim małżeństwie Akwili i Pryscyllii, którzy już prawdopodobnie stali się chrześcijanami Dowiadujemy się najpierw, że Akwila był „Żydem pochodzącym z Pontu, który wraz ze swoją żoną Pryscyllą przybył niedawno z Italii" $(18,2)$. Następna część wersetu wyjaśnia, że ich obecność w Koryncie nie była efektem ich wolnej czy zamierzonej decyzji, ale znaleźli się tam, ponieważ „Klaudiusz nakazał bowiem opuścić Rzym wszystkim Żydom”

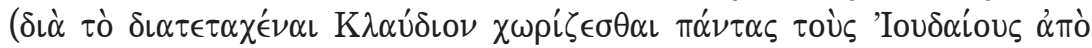

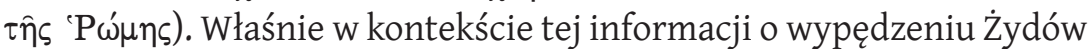
ze stolicy cesarstwa po raz pierwszy pojawia się w Dziejach Apostolskich nazwa Rzym. Fakt ten znany jest także z innych źródeł, szczególnie ze świadectwa Swetoniusza, rzymskiego autora biografii cesarzy, który stwierdza: „Iudaeos impulsore Chresto assidue tumultuantes Romae expulit". Prawdopodobnie przyczyną edyktu Klaudiusza, który zwykle jest datowany między 25 stycznia 49 roku a 24 stycznia 50 roku $^{10}$, były zamieszki wśród Żydów zamieszkujących Rzym, wzniecone z powodu niejakiego Chrestosa (Christusa), który zgodnie z przekonaniem Swetoniusza miał osobiście wzniecać niepokój. Dzieje Apostolskie stwierdzają jedynie, że Klaudiusz wypędził „wszystkich Żydów” ( $\pi \alpha \dot{\nu} \tau \alpha \varsigma$

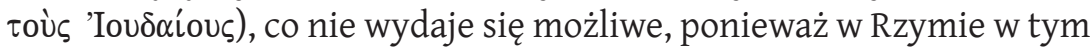
czasie była liczna diaspora żydowska ${ }^{11}$. Skoro małżonkowie zostali jed-

${ }^{7}$ Znane było określenie „postępować po koryncku” na oznaczenie uprawiania w wyszukany sposób rozpusty - zob. J. M. Czerski, Pierwszy List św. Pawła do Koryntian, t. 1 , Opole 2006, s. 41.

${ }^{8}$ H. Langkammer, Dzieje Apostolskie, Lublin 2008, s. 208; W. Rakocy, Paweł Apostoł Żydów i pogan, dz. cyt., s. 107. Co prawda tekst Dziejów Apostolskich podkreśla, że byli Żydami, ale nie przekreśla to możliwości, że stali się już chrześcijanami. Ponadto w kontekście wzmianki o wypędzeniu Żydów z Rzymu, być może Łukaszowi chodzi o podkreślenie ich żydowskiego pochodzenia - zob. H. Conzelmann, Acts of the Apostles, Philadelphia 1987, s. 151.

${ }^{9}$ Tekst świadectwa Swetoniusza cytuję za R. Pesch, Atti degli apostoli, Assisi 1992, s. 702.

${ }^{10} \mathrm{Na}$ temat datacji tego wydarzenia zob. W. Rakocy, Paweł Apostoł, dz. cyt., s. 102-107.

${ }^{11}$ Według R. Pesch, Atti, dz. cyt., s. 702 mogło być około 50 tysięcy Żydów. Wielu autorów podaje różną liczbę diaspory żydowskiej w Rzymie w I wieku. Przegląd róż- 
nak wypędzeni z Rzymu, świadczy to pośrednio, że byli szczególnie aktywni we wspólnocie rzymskiej, a ich umiejętności zaangażowania potwierdza także późniejsza ich działalność w Koryncie, Efezie i ponownie w Rzymie ${ }^{12}$ (1 Kor 16, 19; Rz 16, 3-4).

Według Dziejów Apostolskich Akwila i Pryscylla przybyli „niedawno”

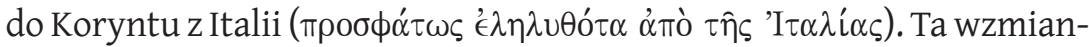
ka może odgrywać ważną rolę dla Łukasza, ponieważ sugeruje ona, że małżonkowie byli w Koryncie krótko, a zatem nie można ich uważać za założycieli pierwszej wspólnoty chrześcijańskiej w tym mieście. Uczynił to dopiero Paweł zgodnie z tym, co czytamy w 1 Kor 3, 6. Mimo że Akwila i Pryscylla przebywali w Koryncie od niedawna, zadomowili się tam na tyle, że mogli udzielić schronienia i pomocy nowemu przybyszowi z Aten. Łukasz informuje czytelnika, że Paweł zamieszkał u nich, ponieważ wykonywał ten sam zawód wyrabiania namiotów $(18,3)^{13}$.W ten sposób małżonkowie, którzy przybyli z Rzymu, pomogli Pawłowi odnaleźć się w nowym miejscu, zapewniając pracę oraz dach nad głową. Od tego momentu Akwila i Pryska ${ }^{14}$ pozostali przyjaciółmi apostoła oraz czynnie uczestniczyli w jego misji ewangelizacyjnej (por. 18, 18. 26; Rz 16, 3; 1 Kor 16, 19; 2 Tm 4, 19).

Pierwsze przywołanie stolicy cesarstwa w Dziejach Apostolskich nie wydaje się mieć jakiegoś szczególnego znaczenia teologicznego. Jest raczej informacją geograficzną, która wyjaśnia powód przybycia Akwili i Pryscylli do Koryntu. Poprzez nawiązanie jednak do konkretnego wydarzenia historycznego (edyktu cesarza Klaudiusza z 49 roku),

nych opinii można znaleźć w R. Penna, L'apostolo Paolo. Studi di esegesie teologia, Cinisello Balsamo 1991, s. 46, przypis 53. Sam autor dowodzi, że mogło być około 20 tysięcy Żydów.

${ }_{12}$ Prawdopodobnie Akwila i Pryscylla powrócili do Rzymu, co było możliwe po śmierci cesarza Klaudiusza w 54 roku. Neron cofną bowiem dekret. Paweł pozdrawia ich w zakończeniu Listu do Rzymian. Apostoł miał zamiar przybyć do Rzymu i liczył na życzliwość i pomoc wspólnoty w przygotowaniu wyprawy do Hiszpanii (Rz 15, 24. 26). Tak oddane mu małżeństwo mogło odegrać ważną rolę w lokalnej wspólnocie rzymskiej, przygotowując ją na przybycie Pawła do stolicy cesarstwa - zob. W. Rakocy, Paweł Apostot, dz. cyt., s. 272.

${ }^{13} \mathrm{Na}$ temat zawodu Pawła zob. J. A. Fitzmyer, Gli Atti degli Apostoli. Introduzione e commento, Brescia 2003, s. 657.

${ }^{14} \mathrm{~W}$ Listach Pawłowych Pryscylla jest nazywana przy pomocy zdrobnienia Pryska (Rz 16, 3; 1 Kor 16, 19 oraz 2 Tm 4, 19). 
umożliwia datację pobytu Pawła w Koryncie, a tym samym całej drugiej podróży misyjnej, która musiała rozpocząć się wiosną 47 roku.

\section{„Muszę jeszcze zobaczyć Rzym” (19, 21)}

Podczas kolejnej podróży misyjnej Paweł przebywał przez jakiś czas w Efezie. Położenie miasta sprzyjało pracy ewangelizacyjnej, a główne szlaki komunikacyjne, które się tam zbiegały, zapewniały szybki i łatwy kontakt z innymi prowincjami Azji. Łukasz skoncentrował swoją uwagę na opowiadaniu o działalności apostoła, poprzez którego „Bóg czynił niezwykłe cuda" $(19,11)$, podkreślając w ten sposób sukcesy apostolskiej działalności Pawła. Zresztą on sam wspomina o tym w 1 Kor 16, 9, pisząc, że przed Ewangelią „otwarła się wielka i obiecująca brama”, choć Paweł miał także świadomość, że „,przeciwnicy są liczni”. Łukasz, opowiadając o pobycie Pawła w Efezie, przytacza kilka epizodów, które jednoznacznie potwierdzają sukcesy ewangelizacyjne: cudotwórcza działalność apostoła (19, 11-12), zwycięska konfrontacja z praktykującymi magię $(19,19)$. Ten okres działalności Pawła został podsumowany przez Łukasza w 19, 20 stwierdzeniem, że „mocą Pana słowo rozszerzało się i utwierdzało" 15.

W trakcie pobytu w Efezie Paweł podjął decyzję udania się do Jerozolimy poprzez Macedonię i Achaję. Bezpośrednim powodem takiej decyzji było dostarczenie do Jerozolimy składki, która została zebrana na potrzeby tamtejszej wspólnoty. Być może Paweł miał zamiar odwiedzić jeszcze inne wspólnoty w Macedonii i Achai, gdzie także przeprowadzono składkę dla braci w Jerozolimie, choć Łukasz wprost tego nie pisze. Jednocześnie w tym samym momencie Paweł postanowił udać się także do Rzymu. Autor Księgi informuje nas o tym, przytaczając bezpośrednio w 19, 21 postanowienie Pawła: „A skoro już tam przybędę - powiedział

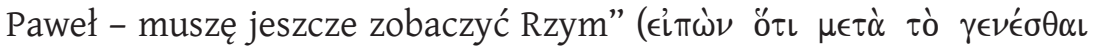

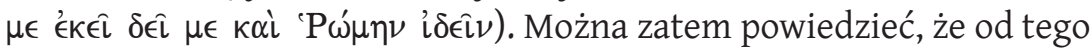
momentu rozpoczęła się podróż Pawła do Rzymu, która jednak wiodła przez Jerozolimę. Kiedy czytamy zapis Łukaszowy o początku tej podróży oraz o decyzji Pawła udania się do stolicy cesarstwa (19, 21-22),

${ }^{15}$ Według niektórych komentatorów werset ten rozpoczyna ostatnią sekcję księgi - zob. W. G. Kümmel, Introduction to the New Testament, London 1975, s. 154-156. 
uderza paralelizm ${ }^{16}$ między tym tekstem a wprowadzeniem do podróży Jezusa do Jerozolimy w Łk 9, 51-52. Zależności literackie ilustruje poniższy schemat:

Dz 19, 21-22

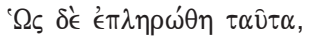

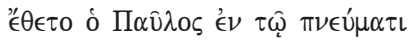
$\pi о \rho \in \cup ́ \in \sigma \theta \alpha \iota$

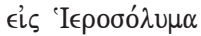

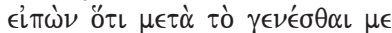

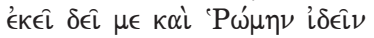

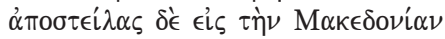

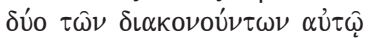

Łk 9, 51-52

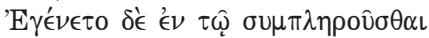
$\tau \grave{\alpha} \varsigma \dot{\eta} \mu \dot{\epsilon}^{\prime} \alpha \varsigma \tau \hat{\eta} \varsigma \dot{\alpha} \nu \alpha \lambda \eta^{\prime} \mu \psi \epsilon \omega \varsigma \alpha \dot{u} \tau o u$

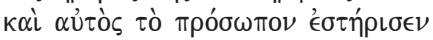

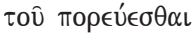

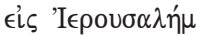

$\kappa \alpha \grave{\iota} \dot{\alpha} \pi \dot{\epsilon} \sigma \tau \epsilon \iota \lambda \epsilon \nu$

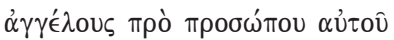

Mamy zatem cztery elementy, które powracają w obu tekstach:(1) wspomnienie zakończenia jakiegoś etapu; (2) decyzja udania się do Jerozolimy (i Rzymu w przypadku Pawła); (3) wysłanie posłańców, którzy poprzedzają głównych bohaterów; (4) podróż jako realizacja woli Boga ${ }^{17}$.

W ten sposób dla Łukasza początek podróży Pawła do Rzymu przez Jerozolimę jest analogicznym wydarzeniem do decyzji Jezusa, który postanawił udać się do Jerozolimy. Nie chodzi tylko o zwykłe powtórzenie, ale w ten sposób Łukasz daje do zrozumienia, że zamierzone udanie się do stolicy cesarstwa jest wynikiem przede wszystkim wypełniania się woli Bożej. Najpierw obie formy czasownikowe, które nawiązują do „wypeł-

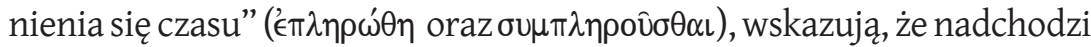
i rozpoczyna się nowy okres przewidziany przez Boga, który przyniesie ważne wydarzenia w historii zbawienia. W przypadku Pawła decyzja udania się do Jerozolimy, a potem do Rzymu została powzięta „w duchu” (' $\epsilon \nu$ $\tau \hat{~} \pi \nu \in \dot{u} \mu \alpha \tau \iota)$, co może być rozumiane jako wewnętrzna decyzja w duchu ludzkim, ale także jako postanowienie, które jest owocem wolnego posłuszeństwa Pawła wobec Bożego planu ${ }^{18}$. Wskazuje na to także kolejny

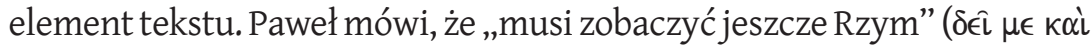

${ }^{16}$ Według J.-N. Aletti, Il racconto come teologia. Studio narrativo del terzo vangelo e del libro degli Atti degli Apostoli, Bologna 2009, s. 71-103 używanie paralelizmów jest dominującą techniką literacką Łukasza. Autor przytacza wiele przykładów. Zestawienie paralelizmów między Jezusem a Pawłem ilustruje tabela na s. 83-84.

${ }^{17}$ E. R. Martinez, Luca-Atti. Un viaggio spirituale (ad uso degli studenti), Roma 1999, s. 41.

${ }^{18}$ R. Pesch, Atti, dz. cyt., s. 738. Niektórzy chcieliby widzieć tutaj bezpośredni wpływ Ducha Świętego.Przeciwko takiej interpretacji występuje J. A. Fitzmyer, Gli Atti, dz. cyt., s. 686. 


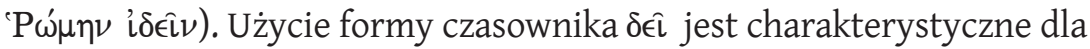
wyrażenia konieczności wypełnienia się planu samego Boga (podobnie $9,16 ; 23,11)^{19}$.Zatem zamierzona podróż do Rzymu jest zgodna całkowicie z Bożymi zamiarami. Stolica cesarstwa staje się zatem celem podróży Pawła, ponieważ także tam ma zanieść Jezusową ewangelię, co staje się jeszcze bardziej oczywiste w świetle następnego tekstu.

\section{„Trzeba, abyś w Rzymie zaświadczył o Mnie” $(23,11)$}

Paweł przybył do Jerozolimy $(21,17)$ i „opowiedział szczegółowo, czego Bóg dokonał dzięki jego pracy wśród pogan" $(21,18)$. Jednak od samego początku jego pobyt we wspólnocie wywołał pewne niepokoje i napięcia podsycane przez radykalnych chrześcijan pochodzenia żydowskiego, którzy zarzucali Apostołowi wzywanie do odstąpienia od Prawa Mojżeszowego $(21,21)$. To było też przyczyną zamieszek na terenie świątyni w Jerozolimie (21, 27-28), w wyniku których Paweł został zatrzymany przez Rzymian $(22,29)$, a następnie postawiony przed Wysoką Radą $(22,30)$. Po przesłuchaniu, które nie pozwoliło ustalić winy Pawła, a jeszcze bardziej skłóciło i doprowadziło do sporów wewnątrz Sanhedrynu $(23,10)$, apostoł został odesłany do koszar, które znajdowały się w twierdzy Antonia. Tam w nocnym widzeniu zobaczył zmartwychwstałego Jezusa, który mu powiedział: „Odwagi! Trzeba, abyś i w Rzymie zaświadczył o Mnie, tak jak to uczyniłeś w Jerozolimie"

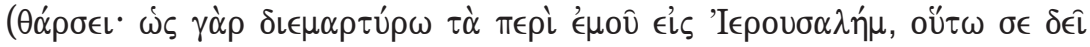

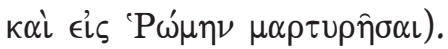

Słowa Zmartwychwstałego nawiązują niewątpliwie do zamiaru Pawła wyrażonego wcześniej w 19, 21. Teraz to sam Jezus nie tylko dodaje mu odwagi i wspiera w chwili próby, ale potwierdza Pawłową decyzję udania się do Rzymu. To, co dotychczas mogło się wydawać tylko pomysłem Pawła, zostaje uznane i potwierdzone autorytetem samego zmartwychwstałego Pana. Ponadto wcześniej była mowa o zamiarze Apostoła, aby

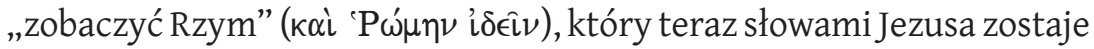

${ }^{19}$ Jezus używa tego samego czasownika w pierwszej zapowiedzi konieczności męki, śmierci i zmartwychwstanie (Łk 9, 22) - zob. E. R. Martinez, Luca-Atti, dz. cyt., s. 42. Na temat tej formy czasownika jako wyrazu „konieczności Bożej” („la necessità divina") zob. s. 49-52. 


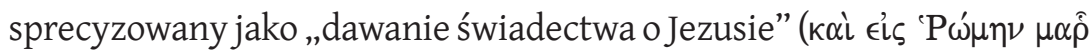

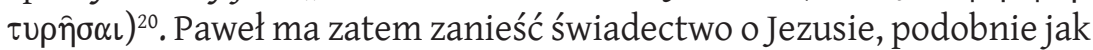
to czynił w Jerozolimie, aż do Rzymu. Misja niesienia świadectwa jest związana z głoszeniem ewangelii ${ }^{21}$, przywoływaniem w pamięci życia Jezusa i wydarzeń, poprzez które dokonało się zbawienie świata, przede wszystkim wydarzenia paschalnego. Podobnie jak wcześniej, wszystko jest wynikiem realizującego się Bożego planu zbawczego (oüt $\omega \sigma \in \delta \hat{l}$ ). Tak więc podróż Pawła do Rzymu będzie rozumiana jako wypełnienie Bożego planu, aby świadectwo o Jezusie mogło dotrzeć do stolicy imperium. Kolejny raz Rzym staje się celem misji ewangelizacyjnej Pawła, która wynika z Bożych zamiarów i zostaje jednoznacznie potwierdzona przez Chrystusa zmartwychwstałego. Jednocześnie Łukasz nadaje także interpretację wydarzeniom w Jerozolimie. Są one okazją do dawania świadectwa o Jezusie i jednocześnie przygotowują Pawła do podróży w kierunku Rzymu. Wszystko jest zgodne z Bożym planem, który konsekwentnie się realizuje. W ten sposób Łukasz zapowiada także dalszy ciąg Dziejów Apostolskich, które opowiadają o podróży Pawła do Rzymu.

\section{„Wreszcie udaliśmy się do Rzymu” $(28,14)$}

Paweł został wkrótce przeniesiony do więzienia w Cezarei Nadmorskiej $(23,23)$, gdzie stanął przed Feliksem (23, 2-27), a następnie przed prokuratorem Porcjuszem Festusem (25, 6-12). Podczas przesłuchania Paweł skorzystał z przywileju, które dawało mu obywatelstwo rzymskie, i odwołał się do cesarza rzymskiego $(25,12)$. Podczas długiej mowy wygłoszonej przed królem Herodem Agryppą II i jego siostrą Berenike Paweł był tak przekonywujący, że król nawet zaproponował Festusowi, że można byłoby go uwolnić, gdyby nie wcześniejsze odwołanie do cesarza (26, 27). Rozpoczęła się zatem podróż w kierunku Rzymu, która jednak okazała się długa i pełna nieprzewidzianych sytuacji. Jak opowiadają Dzieje

${ }^{20}$ Przytoczone tutaj słowa Jezusa przypominają także wypowiedź Pawła z 22, 21, kiedy przemawiając w świątyni jerozolimskiej, wspomina swoją rolę w kamienowaniu Szczepana $(22,20)$ - pilnował szat zabójców. W tym kontekście mówi: „Pan mi powiedział: «Idź, bo poślę cię daleko, do pogan»" $(22,21)$.

${ }^{21}$ R. Filippini, Per una teologia lucana della testimonianza. Un'indagine nel libro degli Atti degli Apostoli, [w:] Testimonianza e verità. Un approccio interdisciplinare, Roma 2000, s. 101-118. 
Apostolskie, po drodze Paweł doświadczył różnego rodzaju niebezpieczeństw i przeciwności, łącznie z rozbiciem statku i koniecznością spędzenia zimy na Malcie. Na początku wiosny 59 roku Paweł wyruszył statkiem z Malty w kierunku Italii. Przybył do Syrakuz, gdzie pozostał trzy dni $(28,12)$, następnie do Regium $(28,13)$ oraz Puteoli, gdzie spędził tydzień u tamtejszych chrześcijan $(28,14 a)$. Po pobycie w tym mieście portowym leżącym na północ od dzisiejszego Neapolu Paweł rozpoczął ostatni pieszy

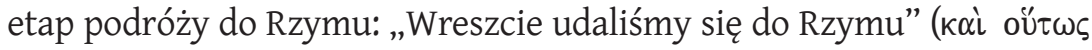

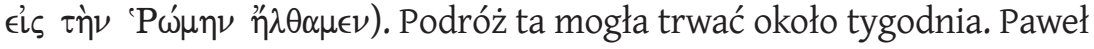
i jego towarzysze przechodzili z pewnością obok Formii, gdzie znajdował się grób Cycerona. Od Terraciny droga wiodła przez tzw. bagna pontyjskie, które August osuszył, prowadząc obok drogi kanał, który mógł być wykorzystany do przewożenia ciężarów ${ }^{22}$. Chrześcijanie rzymscy musieli się dowiedzieć o przybyciu Pawła, bo jak nas informują Dzieje Apostolskie, wyszli mu na spotkanie „aż do Forum Appiusza i Trzech Gospód”23 (28, 15). W ich towarzystwie Paweł dotarł do Wiecznego Miasta. Było to olbrzymie miasto tętniące życiem, które według szacunków mogło mieć około miliona mieszkańców. Większość z nich należała do klas niższych. Byli to niewolnicy, plebejusze, wyzwoleńcy oraz liczni imigranci, którzy przybywali do Rzymu w poszukiwaniu pracy jako rzemieślnicy czy kupcy. Liczną rzeszę mieszkańców ówczesnego Rzymu stanowili przybysze ze Wschodu, często zamieszkujący osobne dzielnice. Wśród nich bardzo silną i zwartą kolonię stanowili Żydzi, co także potwierdzają wykopaliska archeologiczne, które odsłaniają szereg synagog i cmentarzy żydowskich pochodzących z I wieku. To właśnie w obrębie tych wspólnot żydowskich pojawiło się chrześcijaństwo w Rzymie ${ }^{24}$.

Kiedy Paweł przybył do Rzymu, został osiągnięty zamierzony i wyznaczony przez samego Boga cel podróży apostoła. Jego świadek przyszedł z ewangelią do stolicy cesarstwa. Jest jednak oczywiste, że to nie Paweł

${ }^{22}$ A. Paciorek, Paweł Apostoł - Pisma, cz. 1, Tarnów 1997, s. 74.

${ }^{23}$ Forum Appii znajdowało się $65 \mathrm{~km}$ od Rzymu, zaś Tres Tabernae około $50 \mathrm{~km}$ od stolicy - zob. J. A. Fitzmyer, Gli Atti, dz. cyt., s. 838.

${ }^{24}$ A. Paciorek, Paweł Apostoł, dz. cyt., s. 190. Na temat początków chrześcijaństwa w Rzymie zob. R. Penna, Lettera ai Romani, t 1: Rm 1-5. Introduzione, versione, commento, Bologna 2007, s. 20-39. Na temat historii miasta zob. J. A. Fitzmyer, Gli Atti, dz. cyt., s. 656-657 wraz z podstawową bibliografią dotyczącą historii Rzymu. 
jako pierwszy przyniósł ewangelię do Rzymu, bo chrześcijaństwo dotarło do stolicy już w latach czterdziestych pierwszego wieku, choć same jego początki w Rzymie nie są dobrze udokumentowane ${ }^{25}$. Dla Łukasza jednak jest ważne, że nastąpiło przejście Pawła ze świadectwem o Chrystusie zJerozolimy do Rzymu. Autor Dziejów Apostolskich pojmował bowiem misję pierwotnego Kościoła i samego Pawła jako głoszenie ewangelii Jezusowej między Jerozolimą a Rzymem, co było równoznaczne z objęciem dwóch światów: żydowskiego i pogańskiego jednocześnie ${ }^{26}$.

„W Rzymie pozwolono mu zamieszkać

w domu prywatnym" $(28,16)$

Po przybyciu Pawła do Rzymu zastosowano wobec niego areszt domowy. Pozwolono mu zamieszkać w prywatnym mieszkaniu pod

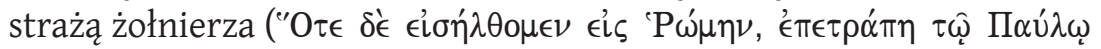

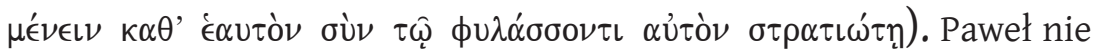
był zatem traktowany jako zagrożenie dla porządku publicznego. Miał spokojnie czekać na rozsądzenie jego sprawy przez trybunał cesarski. Prawdopodobnie chrześcijanie rzymscy pomogli Pawłowi znaleźć mieszkanie w stolicy, a pomimo pozostawania pod strażą żołnierza apostoł cieszył się dość znaczną swobodą przyjmowania gości. Mógłbez przeszkód spotykać się z innymi ludźmi. Jak informują nas Dzieje Apostolskie, już po trzech dniach zaprosił do siebie przedstawicieli wspólnoty żydowskiej w Rzymie $(28,17)$, wobec których wyjaśnił powody swego uwięzienia $(28,17-20)$ oraz rozpoczął misję głoszenia ewangelii Jezusa (28, 23-31).

Najpierw warto zwrócić uwagę na to, że Paweł po przybyciu do Rzymu, stolicy świata pogańskiego, podjął misję wobec Żydów z diaspory rzymskiej. Być może kolejny raz Łukasz w ten sposób zwraca naszą uwagę, że pobyt Pawła w Rzymie, który w naturalny sposób mógłby się kojarzyć z misją wśród pogan, nie wyklucza w żaden sposób Żydów z kręgu jego misyjnych zainteresowań. To oni stają się w pierwszym rzędzie adresatami jego ewangelii. Paweł w swojej działalności misyjnej był bardzo gorliwy:

${ }^{25}$ R. Penna, L'apostolo Paolo, dz. cyt., s. 64-76.

${ }^{26}$ D. Marguerat, Luc-Actes entre Jérusalem et Rome. Un procédé lucanien de double signification, „New Testament Studies” 45 (1999), s. 70-87. Autor zwraca uwagę, że całe dzieło Łukaszowe rozpoczyna się w Jerozolimie (Łk 1-2), a kończy w Rzymie (Dz 28). 
„od rana do wieczora przekonywał ich do wiary w Jezusa Chrystusa" $(28,23)$, szukając odpowiednich argumentów w tradycji żydowskiej, powołując się „,na Prawo, Mojżesza i na Proroków” $(28,23)$. Jak bywało to wcześniej, tak i teraz Paweł zdołał przekonać niektórych, inni zaś nie uwierzyli $(28,24)$. Wobec takiego faktu Paweł stwierdza jednoznacznie, nawiązując do proroctwa Izajasza, że „zbawienie Boże zostało skierowane do pogan i oni je usłyszą". W ten sposób Paweł, wychodząc od swojego osobistego doświadczenia misyjnego, prorocko zapowiada, że ewangelia głoszona będzie poganom i oni ją usłyszą, to znaczy uwierzą i przyjmą ją w posłuszeństwie samemu Bogu.

Ostatnie dwa wersety, które stanowią zakończenie otwarte księgi, informują nas, że Paweł pozostał dwa lata (od wiosny 59 do wiosny 61) w wynajętym przez siebie mieszkaniu i przyjmował wszystkich, którzy przychodzili do niego $(28,30)$. Łukasz wspomina, że Paweł „przyjmował wszystkich" ( $\dot{\alpha} \pi \epsilon \delta \in \dot{\epsilon} \chi \tau 0 \pi \dot{\alpha} \nu \tau \alpha \varsigma)$, co może oznaczać poszczególne osoby, ale także „wszystkich”, to znaczy zarówno Żydów, jaki pogan ${ }^{27}$. Tak zatem misja Pawła obejmuje wszystkich bez wyjątku, nawet w Rzymie pozostaje on apostołem Żydów i pogan. W ten sposób Paweł wiernie wypełnia swoje powołanie bycia świadkiem Jezusa wobec wszystkich ludzi (Dz 22, 15).

Paweł „nauczał o królestwie Bożym i o Panu Jezusie Chrystusie od-

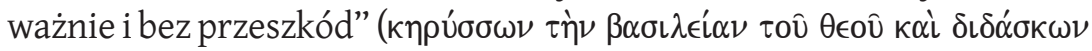

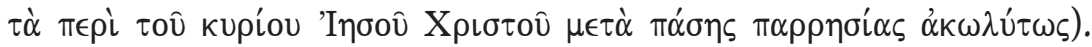
To zakończenie nawiązuje niewątpliwie do prologu księgi, gdzie Łukasz pisze, że zmartwychwstały Jezus ukazywał się apostołom przez czterdzieści dni i mówił im o tym, co odnosi się do królestwa Bożego (Dz 1,3):

Dz 1, 3

$\lambda \epsilon^{\prime} \gamma \omega \nu$

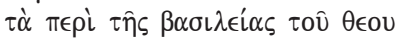

Dz 28, 31

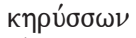

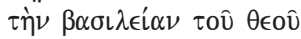

Paweł podjął to samo zadanie. Jak Jezus zmartwychwstały głosił królestwo Boże w Jerozolimie, tak teraz Paweł czyni dokładnie to samo: głosi królestwo Boże w Rzymie. Apostoł kontynuuje zatem misję samego Chrystusa zmartwychwstałego. W sercu jego kerygmatu jest głoszenie królestwa Bożego oraz „nauczanie tego, co dotyczy Pana Jezusa

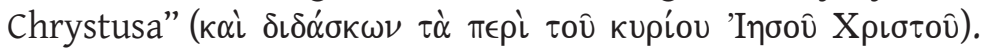

\footnotetext{
${ }^{27}$ Niektóre manuskrypty $(614,2147)$ dodają: „Żydzi i Grecy”.
} 
Przepowiadanie Pawła, skoro dotyczy głoszenia królestwa Bożego, musi odnosić się do zmartwychwstałego Pana, Jezusa z Nazaretu, który jest Mesjaszem Izraela. Warto zwrócić uwagę na podobieństwo także konstrukcji gramatycznej pomiędzy Dz 1, 3 a 28, 31. Na początku Łukasz pisze, że Jezus mówił apostołom o tym wszystkim, co odnosi się do królestwa Bożego", w zakończeniu Paweł naucza „o tym wszystkim, co odnosi się Pana Jezusa Chrystusa":

Dz 1,3

$\lambda^{\prime} \hat{\prime} \gamma \omega \nu$

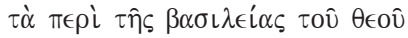

Dz 28, 31

$\delta เ \delta \alpha \dot{\sigma} \sigma \kappa \omega \nu$

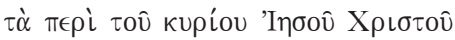

Dla Łukasza jest zatem oczywista tożsamość królestwa Bożego i Jezusa Chrystusa, zmartwychwstałego Pana. Mamy zatem istotne elementy pierwotnego kerygmatu chrześcijańskiego. Na tym polega także misja Pawła, o której mówił mu wcześniej sam Jezus w 23, 11. Paweł miał dawać świadectwo o Jezusie, a zatem przywoływać w pamięci i głosić Jezusa historycznego, Mesjasza Izraela, który poprzez wydarzenie paschalne śmierci i zmartwychwstania jest Panem i w Nim objawia się i przychodzi królestwo Boże.

Paweł podjął się tego zadania głoszenia ewangelii i dawania świadec-

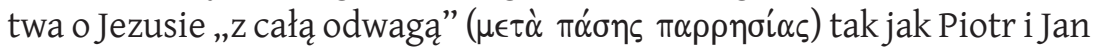

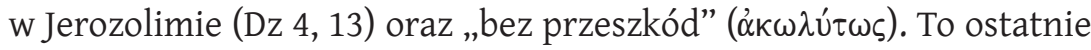
emfatyczne stwierdzenie Łukasz na samym końcu księgi podkreśla, że mimo iż Paweł znajduje się $\mathrm{w}$ areszcie domowym, słowo Boże nie uległo skrępowaniu i bez przeszkód może się rozszerzać $(2 \mathrm{Tm} 2,9)$.

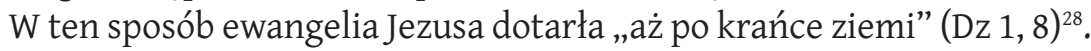
Cel został osiągnięty, polecenie Jezusa zrealizowane, Łukasz może zakończyć także swoje opowiadanie ${ }^{29}$. W ten sposób Dzieje Apostolskie są księgą zakończoną, a jednocześnie otwartą, bo słowo Boże będzie ciągle z odwagą głoszone przez następnych świadków Jezusa, którzy poniosą Jego ewangelię po kolejne krańce ziemi.

${ }^{28}$ J. A. Fitzmyer, Gli Atti, dz. cyt., s. 848-849.

${ }^{29}$ A. Decaux, Święty Paweł, Warszawa 2006, s. 229. 


\section{Podsumowanie}

Nazwa stolicy imperium rzymskiego jest przywołana pięciokrotnie w Dziejach Apostolskich, które opowiadają o rozszerzaniu się ewangelii Jezusowej „aż po krańce ziemi”. Analiza poszczególnych odniesień do Rzymu wykazała, że nie chodzi tylko i wyłącznie o informacje natury geograficznej dotyczące kierunku misji pierwotnego Kościoła i apostoła Pawła. W fakcie przemieszczania się ewangelii ku Rzymowi jest odczytywany Boży plan zbawienia, który obejmuje całą ludzkość, to znaczy zarówno Żydów, jak i pogan. Misja ewangelizacyjna jest postrzegana jako głoszenie ewangelii między Jerozolimą a Rzymem. W mieście Dawidowym wszystko miało swój początek, tam mieszkali przede wszystkim naoczni świadkowie Jezusa, tam zstąpił Duch Święty, który uzdolnił apostołów do bycia świadkami Jezusa najpierw w samej „Jerozolimie, Judei, Samarii i aż po krańce ziemi” (Dz 1, 8). Ale zbawienie nie jest zarezerwowane tylko dla jednego narodu, ono jest dla wszystkich, także dla pogan (Dz 28, 28). Stąd apostołowie rozpoczęli misję, która miała umożliwić wypełnienie Bożego planu zbawienia wszystkich. W tym zadaniu misyjnym szczególne miejsce zajmował Paweł powołany przez Chrystusa zmartwychwstałego, który stał się apostołem Żydów i pogan. Jego misja rozpoczęła się i trwała w jedności ze wspólnotą jerozolimską oraz z apostołami, choć z upływem lat zaczęła ogarniać coraz to nowe tereny zamieszkiwane zarówno przez Żydów, jak i pogan. Można powiedzieć, że jego apostolska misja dokonywała się między Jerozolimą a Rzymem. Paweł miał świadomość konieczności zaniesienia orędzia zbawczego aż po krańce ziemi wszystkim narodom pod niebem i dlatego sam pragnął udać się do Rzymu $(19,21)$. Ta jego determinacja przywołuje, jak powiedzieliśmy, postanowienie samego Jezusa pójścia do Jerozolimy, które było przecież jednoznaczne z wypełnieniem się Bożych planów zbawczych. Paweł podjął takie samo postanowienie, pragnąc, aby w ten sposób w nim i poprzez niego mógł się wypełnić Boży zamiar. Następnie sam Jezus objawił się Pawłowi i potwierdził, że jego powołaniem, które wynika z Bożego planu (Dz 22, 15), było dotarcie ze świadectwem o Nim aż do stolicy imperium, aby i tam głosić Jezusa $(23,11)$. Właściwie od tego momentu wszystko zostało w pewien sposób podporządkowane temu zadaniu, a wydarzenia, w których Paweł 
uczestniczył, stały się kolejnymi etapami realizacji planu Bożego, który konsekwentnie, mimo wielu trudności prowadził apostoła do Rzymu. Kiedy tam przybył, natychmiast z wrodzoną sobie gorliwością podjął powierzoną mu misję i odważnie głosił królestwo Boże, i nauczał o Jezusie $(28,31)$. Jego misja kolejny raz łączyła Żydów i pogan, którzy przyjmując wiarę w Jezusa, zmartwychwstałego Mesjasza, tworzyli jedną wspólnotę uczniów Jezusa Chrystusa. Nie chodziło o zastąpienie misji wśród Żydów ewangelizacją pogan, ale o kontynuację i jedność misji Kościoła adresowanej do wszystkich ludzi.

Rzym jawi się zatem w Dziejach Apostolskich jako symbol realizacji Bożych planów, misji głoszenia dobrej nowiny, która jest przeznaczona dla wszystkich bez względu na przynależność narodową, kulturową i szerokość geograficzną. Rzym jest zatem wpisany w tę „zbawczą geografię” Boga, która wiedzie od Jerozolimy, gdzie dokonało się zbawienie świata, aż po krańce ziemi. Wieczne Miasto staje się symbolem przechodzenia od świata żydowskiego do świata pogańskiego, ale bez wykluczania czy pomijania kogokolwiek. Stolica cesarstwa jest także miejscem kontynuacji misji samego Jezusa oraz odważnego dawania świadectwa Jezusowej ewangelii, którą Paweł poświadczył nie tylko głoszeniem i nauczaniem o Jezusie, ale po kilku zaledwie latach przypieczętował własną krwią świadka-męczennika przelaną właśnie w tym mieście. I tak jak około trzydziestu lat wcześniej ewangelia Jezusowa wyszła z Jerozolimy, aby dotrzeć do Rzymu, tak odtąd z Rzymu promieniuje na cały świat, aby „mocą Pana słowo Boże rozszerzało się i utwierdzało” (Dz 19, 20).

Gniezno

KS. PAWEE PODESZWA

\section{Słowa kluczowe}

Rzym, Dzieje Apostolskie, Paweł, misja ewangelizacyjna, świadectwo

\section{Summary}

„You must also bear witness in Rome” (Acts 23,

11). Rome in the Acts of the Apostles

The article focuses on the analysis of five texts from the Acts of the Apostles where the name Rome $(18,2 ; 19,21 ; 23,11 ; 28,14.16)$ is mentioned. The recurrence of the 
name of the Empire's capital does not only constitute purely geographical information. This is because Rome has come to symbolize the mission of spreading the Good News being directed at all people regardless of their nationality or residence. Consequently, Rome is part of God's "redeeming geography", which has its beginning in Jerusalem (where salvation took place) and reaches all the corners of the globe. Paul's mission between Jerusalem and Rome represents the Gospel leaving the Jewish world in order to reach the pagan world without excluding or neglecting anyone in the process. The Empire's capital is also home to the continuation of the mission of Jesus himself as well as to bearing witness to Jesus' Gospel in a courageous manner. Paul did not only bear witness to the Gospel through his teachings but also, a few years later, as a witness - martyr through his own blood shed in that very City. And just as thirty years earlier Jesus' Gospel had taken roots in Jerusalem only to arrive in Rome, so then it radiate from Rome all over the world so that "the word of the Lord could continue to spread with influence and power" (Acts 19, 20).

\section{Keywords}

Rome, the Acts of the Apostles, Paul, evangelising mission, testimony 
